\title{
Clinical epigenetics and restoring of metabolic health in severely obese patients undergoing batriatric and metabolic surgery
}

\author{
Mario Faenza ${ }^{1}$ - Giuditta Benincasa ${ }^{2}(\mathbb{D})$ - Ludovico Docimo ${ }^{3}$ - Giovanni Francesco Nicoletti ${ }^{1}$ - Claudio Napoli ${ }^{2,4}$
}

Received: 22 July 2021 / Accepted: 28 August 2021 / Published online: 2 October 2021

(c) The Author(s) 2021

\begin{abstract}
Epigenetic-sensitive mechanisms, mainly DNA methylation, mirror the relationship between environmental and genetic risk factors able to affect the sensitiveness to development of obesity and its comorbidities. Bariatric and metabolic surgery may reduce obesity-related cardiovascular risk through tissue-specific DNA methylation changes. Among the most robust results, differential promoter methylation of ACACA, CETP, CTGF, S100A8, and S100A9 genes correlated significantly with the levels of mRNA before and after gastric bypass surgery (RYGB) in obese women. Additionally, promoter hypermethylation of NFKBI gene was significantly associated with reduced blood pressure in obese patients after RYGB suggesting useful non-invasive biomarkers. Of note, sperm-related DNA methylation signatures of genes regulating the central control of appetite, such as MC4R, BDNF, NPY, and CRI, and other genes including FTO, CHST8, and SH2Bl were different in obese patients as compared to non-obese subjects and patients who lost weight after RYGB surgery. Importantly, transgenerational studies provided relevant evidence of the potential effect of bariatric and metabolic surgery on DNA methylation. For example, peripheral blood biospecimens isolated from siblings born from obese mothers before bariatric surgery showed different methylation signatures in the insulin receptor and leptin signaling axis as compared to siblings born from postobese mothers who underwent surgery. This evidence suggests that bariatric and metabolic surgery of mothers may affect the epigenetic profiles of the offspring with potential implication for primary prevention of severe obesity. We update on tissue-specific epigenetic signatures as potential mechanisms underlying the restoration of metabolic health after surgery suggesting useful predictive biomarkers.
\end{abstract}

Keywords Obesity $\cdot$ Bariatric and metabolic surgery $\cdot$ Epigenetics $\cdot$ Precision medicine

\section{Introduction}

Mario Faenza and Giuditta Benincasa have contributed equally.

Giuditta Benincasa

giuditta.benincasa@unicampania.it

1 Multidisciplinary Department of Medical, Surgical and Dental Sciences, Plastic Surgery Unit, University of Campania "Luigi Vanvitelli", Naples, Italy

2 Department of Advanced Medical and Surgical Sciences (DAMSS), University of Campania "Luigi Vanvitelli", Naples, Italy

3 Division of General, Mininvasive and Bariatric Surgery, University of Campania "Luigi Vanvitelli", Via Pansini 5, 80100 Naples, Italy

4 Clinical Department of Internal Medicine and Specialistics, Division of Clinical Immunology, Transfusion Medicine and Transplant Immunology, AOU University of Campania "Luigi Vanvitelli", Naples, Italy
Despite the efforts in discovering novel potential noninvasive biomarkers, we are unable to stratify the risk of recovering the weight lost and developing cardiovascular diseases (CVDs) in severely obese patients undergoing weight change $[1,2]$. Obesity has globally reached epidemic proportions, increasing the risk for type 2 diabetes (T2D) and CVDs as major causes of morbidity and mortality worldwide [3]. Advanced epigenomic-based technologies are providing novel insight into the pathogenesis of obesity and CVDs [3-7]. Direct epigenetic marks consist in DNA methylation and histone modification changes occurring as a response to specific environmental exposures, which can affect gene expression programs without modifications in genetic background [8]. Epigeneticsensitive mechanisms can be acquired over the lifetime leading to chromatin remodeling and, therefore, alterations 
of transcriptional programs underlying oxidative stress, inflammation, and metabolic unbalance which may predispose to obesity [4-8].

Bariatric and metabolic surgery is an effective therapy in the management of severe obesity and related cardiometabolic risk [9-12], and, generally, is suggested to patients with a body mass index (BMI) $\geq 40 \mathrm{~kg} / \mathrm{m}$ [2] who have failed traditional nonsurgical approaches [13-15]. Chronologically, we had Roux-en-Y gastric bypass (RYGB), biliopancreatic diversion (BPD), duodenal switch (DS), adjustable gastric banding (AGB), and sleeve gastrectomy (SG). RYGB, BPD, and DS dominated the scene as gold standards in the surgical treatment of patients with severe obesity from the 1960s to the 2000s and have been replaced by SG. The reason for this change resides in the lower rate of complications both in the short (anastomotic leaks, small bowel obstruction, staple-line leaks, hemorrhage) and long term (anastomotic strictures, marginal ulceration, gastric fistula, nutritional deficiencies, liver failure, and recurrent weight gain) and in the less complexity of the whole surgical procedure [13-15]. In the early 2000s, laparoscopic AGB started to have considerable appeal both for surgeons and patients, given the simple technique and low short-term complication rate; however, the cluster of patients in which this type of procedure was indicated rapidly diminished owing to weight regain and long-term risk of band perforation/slippage [13-15]. SG has the advantage of not requiring any bowel manipulation or anastomosis, but there are no data in the long term and the rate of staple-line leaks in the fundus of the sleeve and gastroesophageal reflux are still high.

The abnormalities of epigenetic-sensitive pathways, mainly guided from DNA methylation, in obese patients undergoing bariatric and metabolic surgery make the epigenetic information potentially useful for diagnostic and therapeutic strategies. Several longitudinal studies demonstrated that bariatric and metabolic surgery may reverse the obesityrelated epigenome, mainly through changes in DNA methylome, suggesting that the epigenetic regulation may mediate the surgery-induced beneficial effects [16-21]. Thus, bariatric and metabolic surgery may serve as "epigenetic shaping" able to restore the metabolic balance in patients affected by severe obesity. The goal of this scoping review is to highlight the relevance of clinical epigenetics as new tool to be employed for clarifying molecular basis of obesity as well as to provide novel biomarkers useful for personalized management of patients after surgical intervention.

\section{Methods}

We performed electronic searches in three different databases, including PubMed, Google Scholar, and Web of Science, to select only studies in patients evaluating the potential clinical role of DNA methylation changes in restoring metabolic health after surgical procedures. We searched for studies written in English with a priority for those published in the last 10 years. The search syntax consisted of terms related to "obese patients" and "metabolic and bariatric surgery" combined with terms "DNA methylation", "peripheral blood", "tissue biopsy", and "biomarkers". Two expert researchers in the field screened independently all studies and categorized them according to the size of the study population and type of human biospecimen. The search yielded 12 original articles evaluating the modifications of DNA methylome in obese patients before and after metabolic and bariatric surgery. Concerning the type of human biospecimen for DNA methylome mapping, five studies used whole blood, two studies used adipose tissue biopsy, three studies used skeletal muscle biopsy, one study used liver biopsy, and one study used spermatozoa.

\section{DNA methylation basic mechanisms}

DNA methylation levels are modulated by environmental and lifestyle risk factors representing potential pathogenic mechanisms underlying metabolic alterations in patients predisposed to or affected by cardiometabolic diseases [4-6, 22]. DNA methylation is the biochemical addition of a methyl group which mainly occurs in the $\mathrm{CpG}$ dinucleotides through the action of DNA methyltransferase enzymes (DNMTs) [8]. The genomic loci with a high density of $\mathrm{CpG}$ dinucleotides [known as "CpG islands", (GCIs)] are mainly located in the gene promoter regions. Generally, CGI methylation status inversely correlates with the rates of transcription regulation; in fact, promoter-related methylated CGIs are located upstream of silenced genes, whereas unmethylated CGIs are located upstream of transcriptionally active genes (Fig. 1) [8]. In contrast, methylation of intragenic regions including gene body untranslated regions (5' and 3' UTRs) seems to be related to increased gene expression [23]. Interestingly, baseline DNA methylation patterns were indicated as possible noninvasive biomarkers which could help to predict weight loss, but advance in this field is still limited to the bench of research laboratory [24].

\section{Obesity-related DNA methylation changes can be erased after metabolic and bariatric surgery}

Beyond the weight loss, bariatric and metabolic surgery can induce several beneficial effects on metabolism including improvement of insulin sensitivity and cardiovascular function as well as resolving T2D $[9,25]$. Specific molecular pathways, including chronic low-grade inflammation, release of incretin hormones, and lipid oxidation and mitochondrial function, seem to be improved after bariatric surgery. 


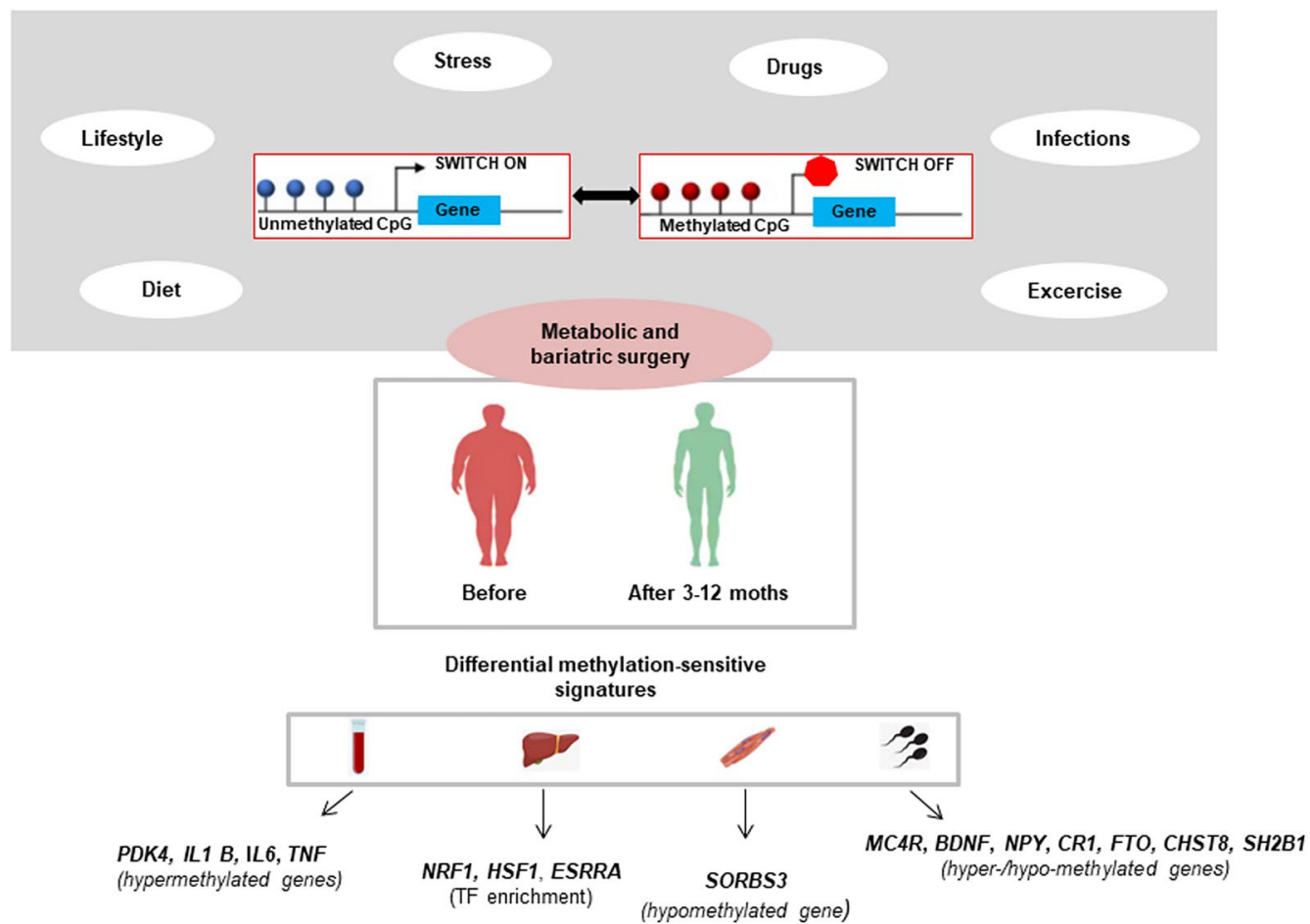

PUTATIVE PREDICTIVE BIOMARKERS

Fig. 1 DNA methylation as potential mediator of bariatric and metabolic surgery effects in patients with severe obesity. DNA methylation changes in targeted genes may mirror the beneficial effects of surgery

[26-29] Even if the molecular routes are still unclear, bariatric and metabolic surgery could restore the metabolic health by means of epigenetic regulation (Fig. 1). In particular, some studies have detected differences in DNA methylation levels upon specific types of bariatric surgery (Table 1). We summarize the most recent clinical evidence for which DNA methylation could mediate the beneficial effects of bariatric and metabolic surgery in specific patient-derived specimens.

\section{Adipose tissue}

The acceleration of visceral adipose tissue (VAT)-related epigenetic age was measured by hypermethylation of specific CpGs and seemed to have potential effects on the process of body weight loss after bariatric and metabolic surgery [30]. Adipose tissue and its DNA methylation profiles have a key role in obese patients [18]. Benton et al. [18] found a cluster of differentially methylated genes in the subcutaneous and omental adipose tissues isolated from obese women before and after an RYGB. These genes were functionally associated with obesity, epigenetic regulation, and development process and showed overlapping modifications in their transcriptional profiles, thus remarking the impact of DNA methylation across surgery procedures [18]. procedures on the weight lost. If mechanistically validated, these molecular signatures may represent useful non-invasive biomarkers to stratify the risk of weight recovery and cardiovascular complications

Besides, Dahlman et al. [31] demonstrated that a specific panel of genes involved in adipogenesis was differentially methylated in their regulatory regions in abdominal subcutaneous fat cells isolated from post-obese women with respect to healthy controls. However, modifications in the related transcriptional profiles were not found [31].

\section{Skeletal muscle}

To date, there is no evidence for the potential effects of RYGB surgery on the global DNA methylation in human tissues, such as muscle biopsy specimens [20, 32]. The methylation levels of the long interspersed nuclear element 1 (LINE-1), considered as a marker of global DNA methylation, did not show changes after RYGB-induced weight loss $[33,34]$. Otherwise, RYGB surgery was significantly associated with targeted modifications in DNA methylation levels of some genes, such as the peroxisome proliferator-activated receptor gamma coactivator 1-alpha $(P G C 1 A)$ and pyruvate dehydrogenase lipoamide kinase isozyme 4 (PDK4), which are involved in the regulation of lipid metabolism in skeletal muscle [20]. After a period of 6 months, modifications in DNA methylation levels were also associated with variations in mRNA levels of these genes, suggesting a potential 


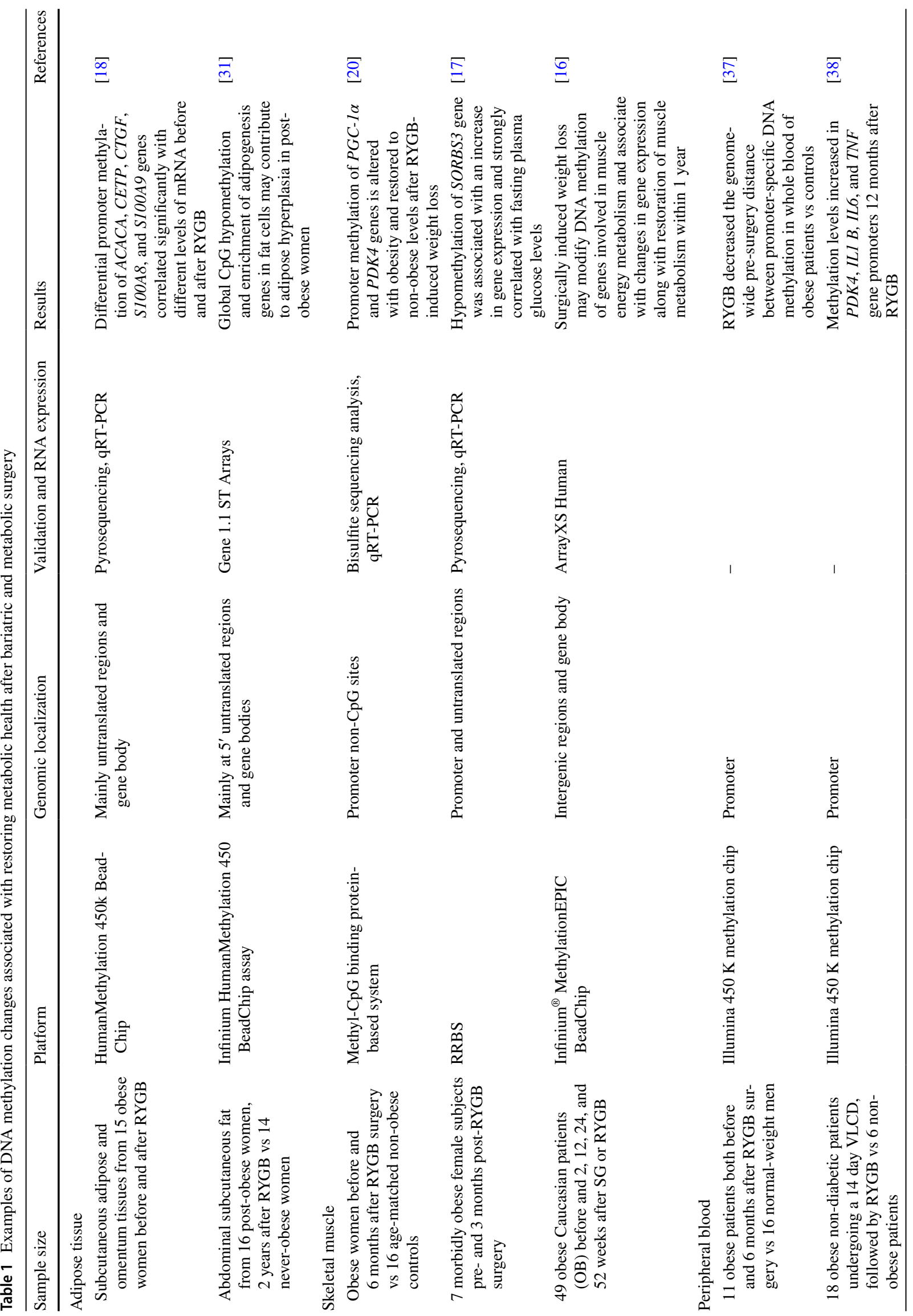




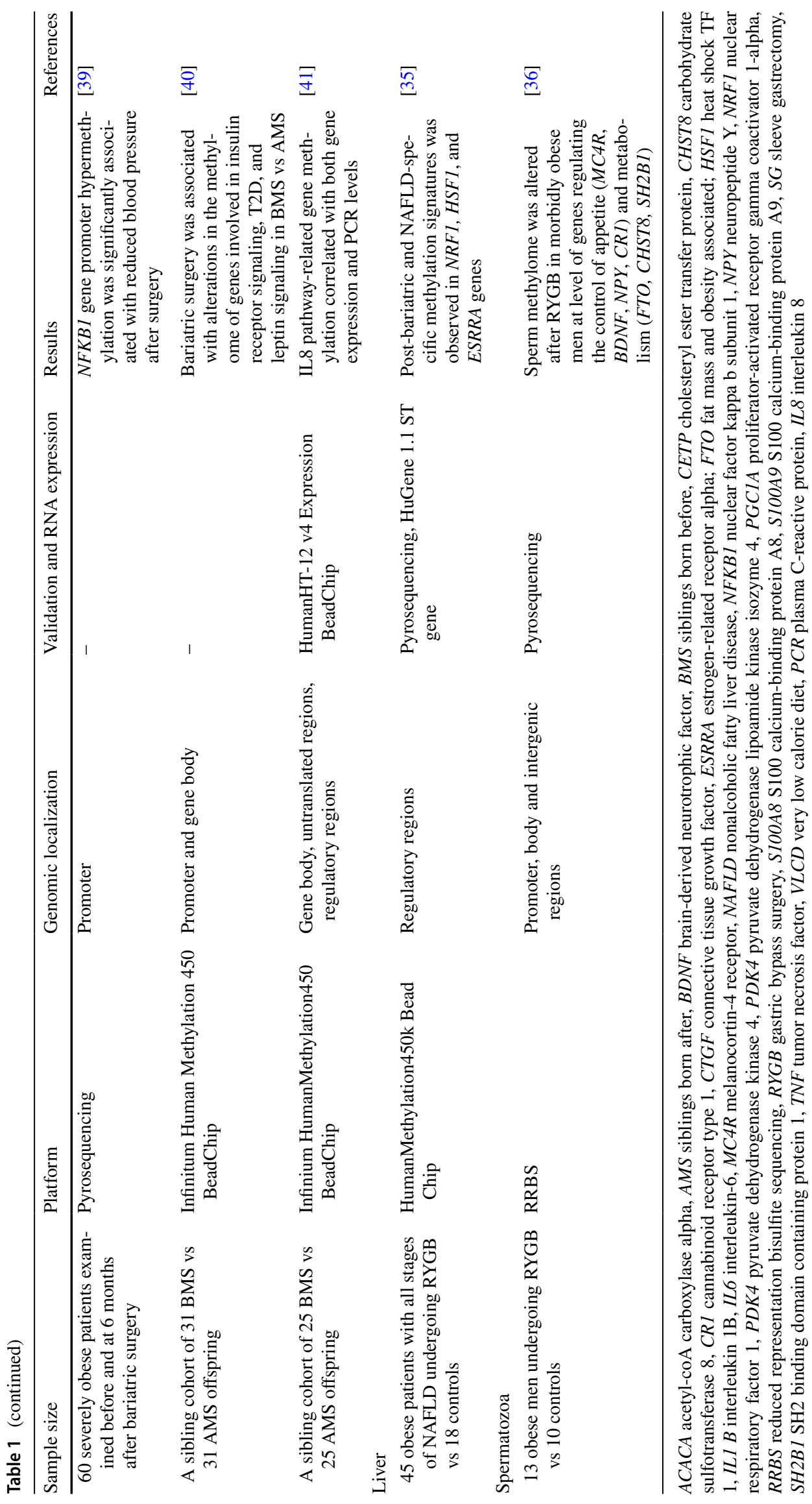


role in restoring metabolic health after surgery [20]. The RYGB-induced weight loss restored to normal levels both the sorbin and SH3 domain containing 3 (SORBS3) promoter methylation levels and gene expression in the muscle specimens of obese female [17]. In addition, post-surgery (at 3 months) changes in the SORBS3 mRNA levels correlated with obesity-related parameters and fasting insulin levels, suggesting molecular routes which were potentially involved in the restoration of metabolic health after surgery procedures [17]. Recently, an integrated omic-based approach has demonstrated that significant changes in DNA methylation mostly occurred both in inter- and intragenic regions at 52 weeks (not early) from the RYGB procedure, affecting the expression profiles of genes involved in mitochondrial, lipidic and calcium-related signaling axes [16].

\section{Liver and spermatozoa}

A case-control study showed an alteration in DNA methylation/transcriptional profiles in liver biopsies isolated from patients with obesity and complicated by different grades of non-alcoholic fatty liver disease (NAFLD) as compared to patients undergoing bariatric surgery [35]. In particular, nine genes encoding for the main enzymes regulating the intermediate metabolism seem to mediate dynamic remodeling, which is induced after the massive weight loss after bariatric surgery [35]. For the first time, sperm biospecimens were collected at three time points from men grouped in three classes: (1) healthy (BMI 20-25), (2) obesity (BMI > 29), and severe obesity (BMI $>40)$ to study whether and how dynamic changes of DNA methylation may have a mechanistic role in obesity [36]. Sperm-related DNA methylation changes mirrored a potential direct involvement of genes regulating the central control of appetite and metabolic processes in obese men as compared to men who lost weight after RYGB suggesting potential biomarkers to longitudinally trace the effect of surgery procedures. [36].

Targeted DNA methylation signatures were detected in blood leukocytes and showed no substantial changes in patients with obesity as compared to healthy controls [37]. Interestingly, Kirchner et al. [38] found that 12 months after RYGB surgery, specific promoter regions annotated to the interleukin (IL)-6,IL-1B, tumor necrosis factor $\alpha$ (TNF- $\alpha$ ), and pyruvate dehydrogenase kinase 4 (PKD4) genes were hypermethylated suggesting a putative mechanistic link between methylation profiles and beneficial effect of bariatric surgery. Interestingly, promoter hypermethylation of the nuclear factor kappa $b$ subunit 1 (NFKB1) gene was significantly associated with reduced blood pressure after surgery suggesting useful non-invasive biomarkers [39].

The potential effects of bariatric and metabolic surgery on DNA methylation are supported by multigenerational studies conducted on obese women before and after bariatric surgery and their offspring. Siblings born from obese mothers before BPD surgery showed different methylation signatures as compared to siblings born from post-obese mothers who underwent surgery. This supports the idea for which the surgical procedure of mothers may modify the epigenetic profiles in the offspring, and, in consequence, the risk of developing cardiovascular complications in adulthood. At molecular level, differentially methylated regions were annotated to insulin receptor and leptin signaling axis in obesity [40]. Besides, the maternal surgical treatment induced differences in the DNA methylation/transcriptional profiles of pro-inflammatory genes in children as compared to their siblings who were conceived pre-surgery [41]. In particular, DNA methylation and transcriptional levels of IL-8-related genes correlated with plasma C-reactive protein levels suggesting useful cardiometabolic risk biomarkers.

\section{Concluding remarks}

Despite that clinical epigenetics is a promising tool for management of cardiometabolic diseases [42-46], the ability to predict outcomes of patients after metabolic and bariatric surgery though DNA methylation changes is still in its infancy. Clinical studies conducted so far are few and small in sample size and performed on different sequencing techniques to map DNA methylome. These non-standardized research protocols did not allow to obtain robust results which would direct the attention toward a biomarker rather than another. Another challenge related to the study of DNA methylation and restoring of metabolic health is the demonstration of a causal-effect relationship between these two factors. One of the most advanced tools to evaluate the presumed causal role of DNA methylation changes in obesity and CVDs is network medicine, which combine advanced omics platforms, potent bioinformatic algorithms, and clinical information [47-49]. Thus, more large longitudinal studies should be conducted to define whether the epigenome profiled before and after metabolic and bariatric surgery may help clinicians in predicting outcomes of severe obese patients.

Funding Open access funding provided by Università degli Studi della Campania Luigi Vanvitelli within the CRUI-CARE Agreement.

\section{Declarations}

Conflict of interest None.

Open Access This article is licensed under a Creative Commons Attribution 4.0 International License, which permits use, sharing, adaptation, distribution and reproduction in any medium or format, as long as you give appropriate credit to the original author(s) and the source, 
provide a link to the Creative Commons licence, and indicate if changes were made. The images or other third party material in this article are included in the article's Creative Commons licence, unless indicated otherwise in a credit line to the material. If material is not included in the article's Creative Commons licence and your intended use is not permitted by statutory regulation or exceeds the permitted use, you will need to obtain permission directly from the copyright holder. To view a copy of this licence, visit http://creativecommons.org/licenses/by/4.0/.

\section{References}

1. Cho JH, Rhee EJ, Park SE, Kwon H, Jung JH, Han KD et al (2019) Maintenance of body weight is an important determinant for the risk of ischemic stroke: a nationwide population-based cohort study. PLoS ONE 14:e0210153. https://doi.org/10.1371/journal. pone. 0210153

2. Macedo CES, da Conti G, Catena AS, Bruneska D, Rosa M, Noronha CG et al (2019) Assessment of TCF7L2 expression after bariatric surgery. PLoS ONE 14:e0216627. https://doi.org/ 10.1371/journal.pone.0216627

3. Friedrich M (2017) Global obesity epidemic worsening. JAMA 318:603. https://doi.org/10.1001/jama.2017.10693

4. Benincasa G, Franzese M, Schiano C, Marfella R, Miceli M, Infante $\mathrm{T}$ et al (2020) DNA methylation profiling of CD04+/ $\mathrm{CD} 08+\mathrm{T}$ cells reveals pathogenic mechanisms in increasing hyperglycemia: PIRAMIDE pilot study. Ann Med Surg (Lond) 60:218-226. https://doi.org/10.1016/j.amsu.2020.10.016

5. Pepin ME, Schiano C, Miceli M, Benincasa G, Mansueto G, Grimaldi $\mathrm{V}$ et al (2021) The human aortic endothelium undergoes dose-dependent DNA methylation in response to transient hyperglycemia. Exp Cell Res 400:112485. https://doi.org/10.1016/j. yexcr.2021.112485

6. Schiano C, Benincasa G, Infante T, Franzese M, Castaldo R, Fiorito $C$ et al (2020) Integrated analysis of DNA methylation profile of $H L A-G$ gene and imaging in coronary heart disease: Pilot study. PLoS ONE 15:e0236951. https://doi.org/10.1371/journal.pone. 0236951

7. Pepin ME, Infante T, Benincasa G, Schiano C, Miceli M, Ceccarelli $S$ et al (2020) Differential DNA methylation encodes proliferation and senescence programs in human adipose-derived mesenchymal stem cells. Front Genet 11:346. https://doi.org/10. 3389/fgene.2020.00346

8. Feinberg AP (2018) The key role of epigenetics in human disease prevention and mitigation. N Engl J Med 378:1323-1334. https:// doi.org/10.1056/NEJMra1402513

9. Benotti PN, Wood GC, Carey DJ, Mehra VC, Mirshahi T, Lent MR et al (2017) Gastric bypass surgery produces a durable reduction in cardiovascular disease risk factors and reduces the long-term risks of congestive heart failure. J Am Heart Assoc 6:e005126. https://doi.org/10.1161/JAHA.116.005126

10. Aung L, Lee WJ, Chen SC, Ser KH, Wu CC, Chong K et al (2016) Bariatric surgery for patients with early-onset vs late-onset type 2 diabetes. JAMA Surg 151:798-805. https://doi.org/10.1001/jamas urg. 2016.1130

11. Hsu CC, Almulaifi A, Chen JC, Ser KH, Chen SC, Hsu KC et al (2015) Effect of bariatric surgery vs medical treatment on type 2 diabetes in patients with body mass index lower than 35: five-year outcomes. JAMA Surg 150:1117-11124. https://doi.org/10.1001/ jamasurg.2015.2602

12. Yska JP, van Roon EN, de Boer A, Leufkens HG, Wilffert B, de Heide LJ et al (2015) Remission of type 2 diabetes mellitus in patients after different types of bariatric surgery: a population-based cohort study in the United Kingdom. JAMA Surg 150:1126-1133. https://doi.org/10.1001/jamasurg.2015.2398

13. Chen Y, Li Z, Dutson E (2020) Primary care treatment of patients following bariatric surgery in 2020. JAMA 324:888-889. https:// doi.org/10.1001/jama.2020.14061

14. Buchwald $\mathrm{H}$ (2014) The evolution of metabolic/bariatric surgery. Obes Surg 24:1126-1135

15. Angrisani L, Santonicola A, Iovino P, Formisano G, Buchwald H, Scopinaro N (2015) Bariatric surgery worldwide 2013. Obes Surg 25:1822-1832

16. Gancheva S, Ouni M, Jelenik T, Koliaki C, Szendroedi J, Toledo FGS et al (2019) Dynamic changes of muscle insulin sensitivity after metabolic surgery. Nat Commun 10(4):179. https://doi.org/ 10.1038/s41467-019-12081-0

17. Day SE, Garcia LA, Coletta RL, Campbell LE, Benjamin TR, De Filippis EA et al (2017) Alterations of sorbin and SH3 domain containing 3 (SORBS3) in human skeletal muscle following Roux-en-Y gastric bypass surgery. Clin Epigenetics 9:96. https:// doi.org/10.1186/s13148-017-0396-5

18. Benton MC, Johnstone A, Eccles D, Harmon B, Hayes MT, Lea RA et al (2015) An analysis of DNA methylation in human adipose tissue reveals differential modification of obesity genes before and after gastric bypass and weight loss. Genome Biol 16:8. https://doi.org/10.1186/s13059-014-0569-x

19. Lips MA, van Klinken JB, Pijl H, Janssen I, van WillemsDijk K, Koning F, van Harmelen V (2016) Weight loss induced by very low calorie diet is associated with a more beneficial systemic inflammatory profile than by Roux-en-Y gastric bypass. Metabolism 65:1614-1620. https://doi.org/10.1016/j.metabol.2016.07. 013

20. Barres R, Kirchner H, Rasmussen M, Yan J, Kantor FR, Krook A et al (2013) Weight loss after gastric bypass surgery in human obesity remodels promoter methylation. Cell Rep 3:1020-1027. https://doi.org/10.1016/j.celrep.2013.03.018

21. Guenard F, Tchernof A, Deshaies Y, Cianflone K, Kral JG, Marceau P et al (2013) Methylation and expression of immune and inflammatory genes in the offspring of bariatric bypass surgery patients. J Obes 2013:492170. https://doi.org/10.1155/2013/ 492170

22. Samblas M, Milagro FI, Martínez A (2019) DNA methylation markers in obesity, metabolic syndrome, and weight loss. Epigenetics 14:421-444. https://doi.org/10.1080/15592294.2019.15952 97

23. Jones PA (2012) Functions of DNA methylation: islands, start sites, gene bodies and beyond. Nat Rev Genet 13:484-492. https:// doi.org/10.1038/nrg3230

24. Milagro FI, Campión J, Cordero P, Goyenechea E, Gómez-Uriz AM, Abete I et al (2011) A dual epigenomic approach for the search of obesity biomarkers: DNA methylation in relation to dietinduced weight loss. FASEB J 25:1378-1389. https://doi.org/10. 1096/fj.10-170365

25. Schauer PR, Mingrone G, Ikramuddin S, Wolfe B (2016) Clinical outcomes of metabolic surgery: efficacy of glycemic control, weight loss, and remission of diabetes. Diabetes Care 39:902-911. https://doi.org/10.2337/dc16-0382

26. Ceccarelli S, Pontecorvi P, Anastasiadou E, Napoli C, Marchese C (2020) immunomodulatory effect of adipose-derived stem cells: the cutting edge of clinical application. Front Cell Dev Biol 8:236. https://doi.org/10.3389/fcell.2020.00236

27. Zhang C, Zhang J, Liu Z, Zhou Z (2018) More than an anti-diabetic bariatric surgery, metabolic surgery alleviates systemic and local inflammation in obesity. Obes Surg 28:3658-3668. https:// doi.org/10.1007/s11695-018-3400-z

28. Ma J, Vella A (2018) What has bariatric surgery taught us about the role of the upper gastrointestinal tract in the regulation of 
postprandial glucose metabolism? Front Endocrinol 9:324. https:// doi.org/10.3389/fendo.2018.00324

29. Fernstrom M, Bakkman L, Loogna P, Rooyackers O, Svensson M, Jakobsson $T$ et al (2016) Improved muscle mitochondrial capacity following gastric bypass surgery in obese subjects. Obes Surg 26:1391-1397. https://doi.org/10.1007/s11695-015-1932-z

30. de Toro-Martín J, Guénard F, Tchernof A, Hould FS, Lebel S, Julien F et al (2019) Body mass index is associated with epigenetic age acceleration in the visceral adipose tissue of subjects with severe obesity. Clin Epigenetics 11:172. https://doi.org/10. 1186/s13148-019-0754-6

31. Dahlman I, Sinha I, Gao H, Brodin D, Thorell A, Rydén M et al (2015) The fat cell epigenetic signature in post-obese women is characterized by global hypomethylation and differential DNA methylation of adipogenesis genes. Int J Obes (Lond) 39:910-919

32. Morcillo S, Macias-Gonzalez M, Tinahones FJ (2017) The effect of metabolic and bariatric surgery on DNA methylation patterns. Curr Atheroscler Rep 19:40. https://doi.org/10.1007/ s11883-017-0676-8

33. Martin-Nunez GM, Cabrera-Mulero A, Alcaide-Torres J, GarciaFuentes E, Tinahones FJ, Morcillo S (2017) No effect of different bariatric surgery procedures on LINE-1 DNA methylation in diabetic and nondiabetic morbidly obese patients. Surg Obes Relat Dis 13:442-450. https://doi.org/10.1016/j.soard.2016.10.014

34. Nicoletti CF, Nonino CB, De Oliveira BA, de Souza Pinhel MA, Mansego ML, Milagro FI et al (2016) DNA methylation and hydroxymethylation levels in relation to two weight loss strategies: energy-restricted diet or bariatric surgery. Obes Surg 26:603-611. https://doi.org/10.1007/s11695-015-1802-8

35. Ahrens M, Ammerpohl O, Von Schonfels W, Kolarova J, Bens S, Itzel $\mathrm{T}$ et al (2013) DNA methylation analysis in non-alcoholic fatty liver disease suggests distinct disease-specific and remodeling signatures after bariatric surgery. Cell Metab 18:296-302. https://doi.org/10.1016/j.cmet.2013.07.004

36. Donkin I, Versteyhe S, Ingerslev LR, Qian K, Mechta M, Nordkap L et al (2016) Obesity and bariatric surgery drive epigenetic variation of spermatozoa in humans. Cell Metab 23:369-378. https:// doi.org/10.1016/j.cmet.2015.11.004

37. Nilsson EK, Ernst B, Voisin S, Almen MS, Benedict C, Mwinyi $\mathrm{J}$ et al (2015) Rouxen $\mathrm{Y}$ gastric bypass surgery induces genomewide promoter-specific changes in DNA methylation in whole blood of obese patients. PLoS ONE 10:e0115186. https://doi.org/ 10.1371/journal.pone.0115186

38. Kirchner H, Nylen C, Laber S, Barrès R, Yan J, Krook A et al (2014) Altered promoter methylation of PDK4, IL1 B, IL6, and TNF after Roux-en Y gastric bypass. Surg Obes Relat Dis 10:671678. https://doi.org/10.1016/j.soard.2013.12.019

39. Macias-Gonzalez M, Martin-Nunez GM, Garrido-Sanchez L, Garcia-Fuentes E, Tinahones FJ, Morcillo S (2018) Decreased blood pressure is related to changes in NF-kB promoter methylation levels after bariatric surgery. Surg Obes Relat Dis 14:1327-1334. https://doi.org/10.1016/j.soard.2018

40. Berglind D, Muller P, Willmer M, Sinha I, Tynelius P, Naslund E et al (2016) Differential methylation in inflammation and type 2 diabetes genes in siblings born before and after maternal bariatric surgery. Obesity 24:250-261. https://doi.org/10.1002/oby.21340

41. Guénard F, Deshaies Y, Cianflone K, Kral JG, Marceau P, Vohl MC (2013) Differential methylation in glucoregulatory genes of offspring born before vs. after maternal gastrointestinal bypass surgery. Proc Natl Acad Sci USA 110:11439-11444. https://doi. org/10.1073/pnas.1216959110

42. Napoli C, Benincasa G, Schiano C, Salvatore M (2020) Differential epigenetic factors in the prediction of cardiovascular risk in diabetic patients. Eur Heart J Cardiovasc Pharmacother 6:239_ 247. https://doi.org/10.1093/ehjcvp/pvz062

43. Schiano C, Benincasa G, Franzese M, Della Mura N, Pane K, Salvatore M et al (2020) Epigenetic-sensitive pathways in personalized therapy of major cardiovascular diseases. Pharmacol Ther 210:107514. https://doi.org/10.1016/j.pharmthera.2020.107514

44. Napoli C, Benincasa G, Donatelli F, Ambrosio G (2020) Precision medicine in distinct heart failure phenotypes: focus on clinical epigenetics. Am Heart J 224:113-128. https://doi.org/10.1016/j. ahj.2020.03.007

45. Costa D, Scognamiglio M, Fiorito C, Benincasa G, Napoli C (2019) Genetic background, epigenetic factors and dietary interventions which influence human longevity. Biogerontology 20:605-626. https://doi.org/10.1007/s10522-019-09824-3

46. Costa D, Benincasa G, Lucchese R, Infante T, Nicoletti GF, Napoli C (2019) Effect of nitric oxide reduction on arterial thrombosis. Scand Cardiovasc J 53:1-8. https://doi.org/10.1080/14017 431.2019.1581943

47. Silverman EK, Schmidt HHHW, Anastasiadou E, Altucci L, Angelini M, Badimon L et al (2020) Molecular networks in network medicine: development and applications. Wiley Interdiscip Rev Syst Biol Med 12:e1489. https://doi.org/10.1002/wsbm.1489

48. Benincasa G, Mansueto G, Napoli C (2019) Fluid-based assays and precision medicine of cardiovascular diseases: the 'hope' for Pandora's box? J Clin Pathol 72:785-799. https://doi.org/10.1136/ jclinpath-2019-206178

49. Benincasa G, Marfella R, Della Mura N, Schiano C, Napoli C (2020) Strengths and opportunities of network medicine in cardiovascular diseases. Circ J 84:144-152. https://doi.org/10.1253/ circj.CJ-19-0879

Publisher's Note Springer Nature remains neutral with regard to jurisdictional claims in published maps and institutional affiliations. 